\title{
MENINGKATKAN HASIL BELAJAR GEOGRAFI MELALUI METODE PEMBELAJARAN MIND MAPPING PADA SISWA DI KELAS XII-IPS 1 SMAN 5 BEKASI PADA TAHUN PELAJARAN 2018/2019
}

\author{
Ida Surtikanti \\ SMA Negeri 5 Bekasi \\ surtikantiida@gmail.com
}

\begin{abstract}
Abstrak
Tujuan penelitian adalah untuk mengetahui bagaimana meningkatkan Hasil Belajar Geografi Melalui Metode Pembelajaran Mind Mapping Pada Siswa di Kelas XII-IPS 1 SMAN 5 Bekasi Pada Tahun Pelajaran 2018/2019. Peneliti menggunakan teknik dan alat pengumpul data yaitu yaitu rubrik dan uraian. Disamping itu, peneliti juga akan menggunakan lembar observasi. Metode penelitian menggunakan penelitian tindakan kelas. Teknik analisis data menggunakan data reduction, data display, dan conclusion drawing/verification. Hasil penelitian yaitu 1. Pada pelaksanaan siklus 1, siswa yang mendapatkan nilai hasil belajar geografi di atas 75 berjumlah 34 siswa yang artinya yang tidak sesuai dengan kriteria keberhasilan tindakan yaitu berjumlah $87,17 \%$ dan siswa yang mendapatkan nilai geografi di atas 75 yaitu berjumlah 5 siswa yaitu berjumlah $12,83 \%$. Oleh karena itu, siklus 2 harus diadakan. 2. Pada pelaksanaan siklus 2, siswa yang mendapatkan nilai hasil belajar geografi di atas 75 berjumlah 39 siswa yang artinya sesuai dengan kriteria keberhasilan tindakan yaitu berjumlah $100 \%$ dan siswa yang mendapatkan nilai geografi di atas 75 yaitu berjumlah $100 \%$ atau 39 siswa. 3. Berdasarkan penjelasan di atas, penggunaan Metode Pembelajaran Mind Mapping dapat Meningkatkan Hasil Belajar Geografi Pada Siswa di Kelas XII-IPS 1 SMAN 5 Bekasi Pada Tahun Pelajaran 2018/2019.
\end{abstract}

Kata kunci: hasil belajar geografi; metode pembelajaran; mind mapping

\section{PENDAHULUAN}

Pendidikan adalah pondasi terbesar untuk membangun sumber daya manusia yang cerdas baik sikap, pengetahuan, dan praktek. Pendidikan yang baik harus dapat memberikan kesempatan yang seluas-luasnya kepada siswa dalam mengembangkan kemampuannya sehingga siswa mampu menerapkan ilmu yang diperoleh untuk kehidupan sehari-harinya.

Pendidikan di suatu Negara pasti mengalami permasalahan baik yang bersifat makro ataupun mikro sehingga Pemerintah perlu membuat suatu terobosan dalam mengembangkan system Pendidikan agar Pendidikan mampu memberikan harapan bagi kemajuan Bangsa Indonesia. Masalah-masalah yang ada yaitu minimnya fasilitas, kurangnya guru di daerah perbatasan, menurunnya kemampuan guru, rendahnya motivasi belajar siswa, dan dan lain-lain.

Salah satu masalah yang terjadi pada proses pembelajaran di SMAN 5 Bekasi yaitu pada pembelajaran Geografi. Pembelajaran yang disajikan oleh guru 
Research and Development Journal Of Education

Vol. 6 No. 1 Oktober 2019

p-ISSN 2406-9744

e-ISSN 2657-1056

belum dapat meningkatkan hasil belajar geografi sehingga guru harus dapat berpikir bagaimana meningkatkan hasil belajar geografi dengan memaksimalkan kemampuan guru dalam menggunakan metode pembelajaran. Salah satu metode pembelajaran yang dapat digunakan untuk meningkatkan hasil belajar geografi adalah mind mapping.

Mind mapping adalah suatu cara guru untuk mengajarkan siswa mengenal peta konsep dari suatu materi sehingga siswa akan mampu untuk memahami konsep tersebut per baba tau per unit. Penggunaan mind mapping dapat membuat siswa mengenal konsep dengan efektif dan tepat tanpa perlu menghabiskan banyak waktu untuk menghafal suatu konsep.

Mata pelajaran geografi harus disajikan dengan kreatif sehingga siswa akan memiliki minat yang tinggi dalam belajar dan siswa akan semangat dalam belajar. Siswa yang memiliki minat dan semangat yang tinggi dalam belajar maka mereka akan belajar dengan serius tetapi penuh dengan kebahagian sehingga hasilnya akan memberikan dampak yang positif bagi peningkatan hasil belajar geografi siswa.

Permasalahan lainnya yang ada pada proses pembelajaran geografi adalah siswa tidak berani untuk mengekspresikan dirinya yaitu unuk sekedar bertanya tentang materi yang belum dikuasai, siswa masih malu dan tidak berani.

Berdasarkan permasalahan di atas, peneliti ingin mengadakan penelitian tindakan kelas dengan judul, Meningkatkan Hasil Belajar Geografi Melalui Metode Pembelajaran Mind Mapping Pada Siswa di Kelas XII-IPS 1 SMAN 5 Bekasi Pada Tahun Pelajaran 2018/2019.

\section{TINJAUAN PUSTAKA}

\section{Pengertian Hasil Belajar Geografi}

Menurut Bloom (Supriono,2009:6-7), hasil belajar terdiri dari aspek kognitif, afektif, dan psikomotorik. Aspek kognitif adalah pengetahuan, pemahaman, menerapkan, menganalisis, mengorganisasikan, dan mengevaluasi. Aspek afektif adalah sikap menerima, memberikan respons, nilai, organisasi. Aspek psikomotor meliputi initiatory, pre-routine, dan rountinized. Psikomotor juga terdiri dari kemampaun produktif, teknik, fisik, sosial, mengatur, dan kecerdasaan intelektual. 
Research and Development Journal Of Education

Vol. 6 No. 1 Oktober 2019

p-ISSN 2406-9744

e-ISSN 2657-1056

Penulis menyimpulkan bahwa hasil belajar terdiri dari 3 ranah yaitu kogntif, afektif, dan psikomotorik. Ketiga domain tersebut memiliki tahapan dalam berpikir sehingga guru dalam merumuskan suatu indikator pencapaian kemampuan harus berurutan tidak boleh mengacak yang pada akhirnya siswa tidak akan mampu untuk mengerjakan soal yang diberikan oleh guru.

Menurut Sudjana, (2014:22), Pengertian hasil belajar adalah kemampuankemampuan yang dimiliki siswa setelah menerima pengalaman belajarnya. Menurut W. Winkel ( 2016:82), Definisi hasil belajar adalah keberhasilan yang dicapai oleh siswa, yakni prestasi belajar siswa di sekolah yang mewujudkan dalam bentuk angka. Menurut Lindgren (dalam Supriono,2009:7), Hasil pembelajaran meliputi keterampilan atau kemampuan, memberi dan menerima informasi, memahami permasalahan belajar, dan sikap baik."

Dapat disimpulkan bahwa hasil belajar adalah kemampuan siswa yang diperoleh setelah melakukan proses belajar mengajar dan pembelajaran dan hasil belajar disimbolkan dengan nilai yang menggambarkan kemampuan siswa pada mata pelajaran tertentu.

Menurut Dimyati dan Mudjiono (2013: 3), hasil belajar adalah hasil dari suatu komunikasi dalam proses belajar dan pembelajaran dan pada kegiatan akhir, guru menilai hasil belajar siswa berdasarkan hasil kerja siswa yang akan digunakan untuk mengetahui kemampuan siswa. Menurut Hamalik (2014:49), Mendefinisikan hasil belajar sebagai tingkat penguasaan yang dicapai oleh pelajar dalam mengikuti proses belajar mengajar sesuai dengan tujuan pendidikan yang ditetapkan. Menurut Susanto (2013: 5), Pengertian hasil belajar adalah perubahan yang terjadi pada diri siswa, baik yang menyangkut aspek kognitif, afektif, dan psikomotor.

Penulis menyimpulkan bahwa hasil belajar adalah perubahan tingkah laku dari yang tidak tahu menjadi tahu pada aspek kognitif, afektif, dan psikomotor.

Menurut R Bintarto dalam Sumadi (2013:4) geografi adalah ilmu yang mempelajari hubungan kasual gejala muka bumi dan peristiwa yang terjadi di muka bumi baik fisik maupun yang menyangkut makhluk hidup beserta pemersalahannya melalui pendekatan keruangan, ekologi dan kewilayahan. 
Research and Development Journal Of Education

Vol. 6 No. 1 Oktober 2019

p-ISSN 2406-9744

e-ISSN 2657-1056

Hakekat geografi adalah pengkajian secara holistic (menyeluruh) melalui pendekatan keruangan, kewilayahan, ekologi dan kesisteman, serta histories terhadap serangkaian gejala dan perihal kehidupan manusia di suatu wilayah tertentu (di permukaan bumi) dan penyajian pengkajian tersebut disampaikan melalui alat peraga peta, grafik, model atau sistem informasi geografi (Widyo Alfandi,2011:87).

Penulis menyimpulkan bahwa geografi adalah ilmu yang mempelajari tentang bumi dan peristiwa yang terjadi di muka bumi, serta mempelajari mengenai mahluk hidup dan benda-benda yang ada di muka bumi. Dalam mempelajari geografi guru bisa menggunakan media pembelajaran seperti peta, dan lain-lain. Geografi asal kata dari bahasa Yunani, "geo" artinya "bumi" dan "graphein"artinya "lukisan" atau "tulisan. Sedangkan,Eratosthenes, "geographika" artinya "tulisan tentang bumi" (Sumaatmadja, 2018: 31). Arti bumi tidak hanya berbicara fisik tetapi bagaimana proses bumi terbentuk. Oleh karena itu, geografi juga berbicara tentang tumbuh-tumbuhan, binatang, dan manusia sebagai penghuni bumi tersebut.

Menurut Richoffen (dalam Hartshorne, 2014: 173) bahwa "Geography is the study of the eart surface according to its differences, or the study of different areas of the earth surface, in term of total characteristics". Bagi Richoffen bahwa bidang kajian geografi tidak hanya mengumpulkan bahan-bahan yang kemudian disusun secara sistematik, tetapi harus dilakukan penghubungan bahan-bahan tersebut untuk dikaji sebab akibatnya dari fenomena-fenomena di permukaan bumi yang memberikan sifat individualitas sesuatu wilayah. Sebab ruang lingkup geografi tidak sekedar fisik, melainkan juga termasuk gejala manusia dan lingkungan lainnya.

Begitu juga menurut Vidal de la Blache yang dikutip dari https://docplayer.info/29881218-Geografi-a-pengertian-dan-ruang-lingkup-ilmugeografi.html. (2015-1919) dari Prancis yang dikenal sebagai "Bapak Geografi Sosial Modern", mengemukakan bahwa "geography is the science of places, concerned with qualities and potentialities of contries" (Hartshorne, 2014:13). Kemudian Karl Ritter misalnya menyatakan bahwa "geography to study the earth as the dwelling-place of man". "The dwellingplace of man" artinya bumi tidak hanya terbatas pada bagian permukaan 
Research and Development Journal Of Education

Vol. 6 No. 1 Oktober 2019

p-ISSN 2406-9744

e-ISSN 2657-1056

bumi yang dihuni manusia, tetapi, wilayah-wilayah yang tidak dihuni manusia. Oleh karena itu, wilayah studi geografi yaitu semua fenomena yang terdapat di permukaan bumi, baik alam organiknya maupun alam anorganiknya dalam interelasi dan interaksinya dalam ruang (spatial relationship). Oleh karena itu menurut Hartshorne (2014: 47): "geography is that discipline that seeks to describe and interpret the variable character from place to place of earth as the world of man”. Preston E. James (2012:11): “Geography has sometimes been called the mother of sciences, since many fields of learning that started with observations of the actual face of earth turned to the study of specific processes whereever they might be located". Disimpulkan geografi adalah induknya ilmu pengetahuan karena banyak aspek keilmuwan yang diawali dengan kegiatan observasi mengenai bagaimana seseatu dipelajari proses kejadiannya.

Hasil penelitian UNESCO (2015: 12-35), maupun Lounsbury (2015: 16): Pertama, geografi sebagai suatu sintesis. Artinya pembahasan geografi itu pada hakikatnya dapat menjawab substansi pertanyaan-pertanyaan tentang; "apa, dimana, kapan, kenapa, dan bagaimana”. Kedua, geografi sebagai suatu penelaahan gejala dan relasi keruangan. Geografi berperan sebagai alat analisis terhadap fenomena-fenomena baik alamiah maupun insaniah. Ketiga, geografi sebagai disiplin tataguna lahan. Keempat, geografi sebagai bidang ilmu penelitian yang dapat bermanfaat bagi manusia dalam mengelola alam dan menjaga kelestarian alam. (Sumaatmadja, 2018: 41).

\section{Pengertian Metode Pembelajaraan Mind Mapping}

Metode Mind Mapping (Peta Pikiran) adalah metode pembelajaran yang dikembangkan oleh Tony Buzana, kepala Brain Foundation. Peta pikiran adalah metode mencatat kreatif yang memudahkan kita mengingat banyak informasi. Setelah selesai, catatan yang dibuat membentuk sebuah pola gagasan yang saling berkaitan, dengan topik utama di tengah, sementara subtopik dan perincian menjadi cabang-cabangnya.

Swadarma (2013: 3) menyatakan mind mapping terdiri dari kata mind dan mapping (Mind adalah pemikiran, mapping adalah cara mencatat yang efektif, efisien, kreatif, menarik, mudah, dan berdaya guna karena dilakukan 
Research and Development Journal Of Education

Vol. 6 No. 1 Oktober 2019

p-ISSN 2406-9744

e-ISSN 2657-1056

dengan cara memetakan pikiran-pikiran kita). Mind mapping merupakan hasil penemuan seorang ahli psikologi bernama Tony Buzan pada awal tahun 1970. Mind mapping merupakan salah satu model mengingat informasi atau ide yang berasal dari proses kerja otak dalam merekam informasi (Wolff, 2004: 32). Menurut Olivia (2014: 7) dengan menggunakan mind mapping penulisan catatan akan lebih menarik secara visual, sehingga bisa membantu kita mengelola informasi saat kita terima, bisa menambahkan kaitan dan asosiasi baru, serta menjadikan informasi lebih lama bertahan dalam ingatan.

Pada umumnya catatan dibuat berbentuk kalimat-kalimat yang disusun secara linier ke bawah atau yang disebut linear note, cara seperti ini memiliki berbagai kelemahan diantaranya adalah (1) monoton, membosankan dan kaku, (2) sulit untuk melihatnya secara utuh, (3) hanya terpusat pada otak kiri, (4) sukar untuk mencari kata kunci dan melihat hubungan antar sub-sub bagian. Umumnya siswa cenderung membuat catatan dalam bentuk linier dan panjang sehingga siswa mengalami kesulitan dalam mencari pokok ataupun poin-poin materi pelajaran yang telah dipelajari. Dalam model konvensional siswa tidak terlibat banyak dari segi berpikir dan bertindak. Siswa hanya menerima informasi yang telah diberikan oleh guru tanpa adanya keterlibatan secara psikomotoriknya. Berdasarkan uraian-uraian di atas peneliti menyimpulkan bahwa mind mapping adalah proses memetakan pikiran untuk menghubungkan konsep-konsep tertentu dari cabang-cabang yang dituangkan melalui gambar.

Langkah-langkah pembuatan mind mapping menurut Buzan (2007: 15) adalah : 1) Sediakan kertas putih pada posisi landscape, letakkan pokok masalah di tengah kertas. Maksudnya untuk memberi kebebasan kepada sswa untuk berpikir kreatif . 2) Siswa diberikan tugas untuk menggambar poko pikiran dan sub-subnya yang dimaksudkan untuk membuat siswa memunculkan ide pikirannya. 3) Siswa harus diberikan tugas untuk memberi warna yang cocok dalam gambar tersebut agar gambarnya menjadi lebih menarik. 4) Siswa diminta untuk menghubungkan cabang utama dengan sub pokok masalahnya. 5) Siswa diminta untuk membuat garis lengkung seperti cabang pohon. 6). Siswa diminta untuk menggunakan satu kata kunci untuk setiap garis sub pokok bahasan. 
Research and Development Journal Of Education

Vol. 6 No. 1 Oktober 2019

p-ISSN 2406-9744

e-ISSN 2657-1056

.7) Siswa diminta membuat gambar atau simbol untuk memberi deskripsi pada sub pokok bahasan.

Menurut Buzan (2007:5), mind mapping memberi gambaran yang lengkap pada pokok masalah atau area yang luas. Manfaat lainnya, merencanakan jalan, membuat pilihan-pilihan, mengetahui jalan pikiran kita, Kita dengan mind mapping dapat mengumpulkan sejumlah besar data di satu tempat. Selanjutnya, mind mapping memberikan cara pemecahan masalah dengan membiarkan siswa berpikir kreatif. Kelebihan lainnya, Mind mapping menyenangkan untuk dilihat, dibaca, dicerna dan diingat. Selain itu, Buzan (2007: 6) menyebutkan kelebihan mind mapping adalah: 1) Merencananakan.

2) Berkomunikasi dengan orang lain 3) Menghemat waktu pembelajaran 4) Menyelesaikan masalah dalam belajar 5) Memusatkan perhatian masalah yang akan dipelajari 6)Menyusun dan menjelaskan pikiran-pikiran yang sulit menjadi sederhana.7) Mengingat dengan lebih baik karena setiap permasalahan dipetakan 8) Belajar lebih cepat dan efesien dan bermakna 9) Melihat gambar permasalahan keseluruhan menjadi sederhana.

\section{METODE}

Penulis menggunakan metode penelitian tindakan kelas atau classroom action research.. Subyek penelitian yaitu Siswa Kelas XII-IPS 1 di SMAN Bekasi Tahun Pelajaran 2018/2019 yang berjumlah 39 siswa. Sumber data penelitian ini adalah Siswa Kelas XII-IPS 1 di SMAN 5 Bekasi Tahun Pelajaran 2018/2019, dan kolaborator yaitu teman sejawat di SMAN 5 Bekasi yaitu guru Geografi kelas XI. Peneliti menggunakan rubrik penilaian untuk menilai hasil belajar Geografi dan untuk mengamati proses pembelajaran di dalam kelas baik pada guru dalam mengajar dan siswa dalam belajar mata pelajaran, peneliti menggunakan lembar observasi. Teknik analisis data menggunakan data reduction, data display, dan conclusion drawing/verification. 


\section{HASIL DAN PEMBAHASAN}

\section{Siklus Pertama}

\section{a. Perencanaan}

Peneliti merancang pembelajaran geografi dengan menggunakan metode pembelajaran mind mapping, membuat soal untuk mengukur hasil belajar bahasa geografi, membuat lembar observasi untuk mengobservasi kegiatan pembelajaran di dalam kelas. Peneliti juga berdiskusi dengan teman sejawat untuk mempersiapkan RPP dan instrumen hasil belajar geografi.

\section{b. Pelaksanaan}

1. Kegiatan Pendahuluan

a. Apersepsi: guru menyapa siswa dan mengabsen.

b. Guru bertanya tentang wilayah formal dan fungsional.

2. Kegiatan Inti

a. Guru meminta siswa untuk menyiapkan kertas karton kertas putih pada posisi landscape dan spidol berwarna dan siswa diminta untuk membuat peta konsep materi wilayah dan pewilayahan. Siswa diminta membuat bentuk segi empat atau lingkaran untuk membuat pokok masalah yang akan dipetakan dengan sub pokok.

b. Siswa diminta membuat sub-sub dari pokok materi dengan menggunakan segi empat atau lingkaran dan siswa menambahkan dengan garis-garis yang menunjukan hubungan antara pokok materi dengan sub materi. Siswa boleh menambahkan dengan gambar-gambar yang sesuai dengan materi dan siswa disarankan untuk mewarnai peta konsep tersebut.

c. Siswa bisa membuat garis lengkung seperti cabang pohon. Garis lengkung yang teratur lebih menarik daripada garis lurus yang membuat otak bosan.

d. Gunakan satu kata kunci untuk setiap garis sub pokok bahasan. Kata kunci tunggal memberikan lebih banyak daya dan fleksibelitas dalam mind mapping.

e. Gunakan gambar atau simbol untuk memberi deskripsi pada sub pokok bahasan. Gambar digunakan untuk mewakili banyak kata- 
Research and Development Journal Of Education

Vol. 6 No. 1 Oktober 2019

p-ISSN 2406-9744

e-ISSN 2657-1056

kata. Dengan gambar, kata-kata rumit yang banyak dapat terangkum dalam sebuah gambar.

3. Kegiatan Penutup

a. Mendorong siswa untuk melakukan, menyimpulkan, merefleksi, dan menemukan nilai-nilai yang dapat dipetik dari aktivitas hari ini.

b. Guru mengajukan beberapa pertanyaan secara lisan untuk menguji wawasan siswa mengenai materi yang telah disampaikan.

c. Mengingatkan siswa untuk bersyukur atas kekuasaan Tuhan yang mampu menciptakan makhluk hidup dan alam dengan bermacam peranan dan manfaat untuk kehidupan.

d. Memberikan penghargaan (pujian dalam lisan atau tulisan) kepada kelompok atau individu berkinerja baik.

Siswa yang mendapatkan nilai hasil belajar geografi di atas 75 berjumlah 34 siswa yang artinya yang tidak sesuai dengan kriteria keberhasilan tindakan yaitu berjumlah $87,17 \%$ dan siswa yang mendapatkan nilai geografi di atas 75 yaitu berjumlah 5 siswa yaitu berjumlah $12,83 \%$. Oleh karena itu, siklus 2 harus diadakan.

Hasil observasi diperoleh nilai $64 \%$ yang artinya kegiatan pembelajaran yang disampaikan oleh guru masih kurang.

Berikut ini terdapat beberapa evaluasi dari pelaksanaan siklus I yang perlu dicari solusinya serta perlu adanya perbaikan untuk peningkatan pada siklus selanjutnya:

1. Guru harus Memberi kesempatan kepada siswa untuk mengembangkan kemampuannya dalam belajar.

2. Guru harus Memotivasi siswa siswa untuk lebih giat belajar dan Menginformasikan materi pelajaran yang akan dipelajari pada pertemuan berikutnya.

3. Guru harus Mengaitkan pengetahuan prasyarat dengan materi yang akan dipelajari dan Memberi kesempatan siswa untuk bertanya. 


\section{Siklus Kedua}

\section{a. Perencanaan}

Peneliti merancang pembelajaran geografi dengan menggunakan metode pembelajaran mind mapping, membuat soal untuk mengukur hasil belajar bahasa geografi, membuat lembar observasi untuk mengobservasi kegiatan pembelajaran di dalam kelas. Peneliti juga berdiskusi dengan teman sejawat untuk mempersiapkan RPP dan instrumen hasil belajar geografi. Kegiatan-kegiatan dalam perencanaan didasarkan pada masukan dari hasil refleksi siklus 1 .

\section{b. Pelaksanaan}

1. Kegiatan Pendahuluan

a. Apersepsi: guru menyapa siswa dan mengabsen.

b. Guru memberikan motivasi belajar kepada siswa.

c. Guru bertanya tentang wilayah formal dan fungsional.

2. Kegiatan Inti

a. Guru memberikan contoh kepada siswa bagaimana membuat peta konsep dengan baik dan benar.

b. Guru meminta siswa untuk menyiapkan kertas karton kertas putih pada posisi landscape dan spidol berwarna dan siswa diminta untuk membuat peta konsep materi wilayah dan pewilayahan. Siswa diminta membuat bentuk segi empat atau lingkaran untuk membuat pokok masalah yang akan dipetakan dengan sub pokok.

c. Siswa diminta membuat sub-sub dari pokok materi dengan menggunakan segi empat atau lingkaran dan siswa menambahkan dengan garis-garis yang menunjukan hubungan antara pokok materi dengan sub materi. Siswa boleh menambahkan dengan gambar-gambar yang sesuai dengan materi dan siswa disarankan untuk mewarnai peta konsep tersebut.

d. Siswa bisa membuat garis lengkung seperti cabang pohon. Garis lengkung yang teratur lebih menarik daripada garis lurus yang membuat otak bosan. 
Research and Development Journal Of Education

Vol. 6 No. 1 Oktober 2019

p-ISSN 2406-9744

e-ISSN 2657-1056

e. Gunakan satu kata kunci untuk setiap garis sub pokok bahasan. Kata kunci tunggal memberikan lebih banyak daya dan fleksibelitas dalam mind mapping.

f. Gunakan gambar atau simbol untuk memberi deskripsi pada sub pokok bahasan. Gambar digunakan untuk mewakili banyak kata-kata. Dengan gambar, kata-kata rumit yang banyak dapat terangkum dalam sebuah gambar.

g. Guru memberikan kesempatan kepada siswa untuk bertanya mengenai materi yang belum dipahami.

h. Guru memberikan jawaban kepada siswa.

3. Kegiatan Penutup

a. Mendorong siswa untuk melakukan, menyimpulkan, merefleksi, dan menemukan nilai-nilai yang dapat dipetik dari aktivitas hari ini.

b. Guru mengajukan beberapa pertanyaan secara lisan untuk menguji wawasan siswa mengenai materi yang telah disampaikan.

c. Mengingatkan siswa untuk bersyukur atas kekuasaan Tuhan yang mampu menciptakan makhluk hidup dan alam dengan bermacam peranan dan manfaat untuk kehidupan.

d. Memberikan penghargaan (pujian dalam lisan atau tulisan) kepada kelompok atau individu berkinerja baik.

Siswa yang mendapatkan nilai hasil belajar geografi di atas 75 berjumlah 39 siswa yang artinya sesuai dengan kriteria keberhasilan tindakan yaitu berjumlah $100 \%$ dan siswa yang mendapatkan nilai geografi di atas 75 yaitu berjumlah $100 \%$ atau 39 siswa.

Hasil observasi diperoleh nilai 98,66 \% yang artinya kegiatan pembelajaran yang disampaikan oleh guru sangat baik.

Berikut ini terdapat beberapa evaluasi dari pelaksanaan siklus II yaitu guru harus dapat menata kelas dengan baik dan membuat siswa untuk terkontrol dalam pembelajaran. Guru dalam memotivasi belajar siswa harus dengan cara-cara yang kreatif dan inovatif.

Pada pelaksanaan siklus 1, siswa yang mendapatkan nilai hasil belajar geografi di atas 75 berjumlah 34 siswa yang artinya yang tidak sesuai dengan 
Research and Development Journal Of Education

Vol. 6 No. 1 Oktober 2019

p-ISSN 2406-9744

e-ISSN 2657-1056

kriteria keberhasilan tindakan yaitu berjumlah 87,17 \% dan siswa yang mendapatkan nilai geografi di atas 75 yaitu berjumlah 5 siswa yaitu berjumlah $12,83 \%$. Oleh karena itu, siklus 2 harus diadakan.

Pada pelaksanaan siklus 2, siswa yang mendapatkan nilai hasil belajar geografi di atas 75 berjumlah 39 siswa yang artinya sesuai dengan kriteria keberhasilan tindakan yaitu berjumlah $100 \%$ dan siswa yang mendapatkan nilai geografi di atas 75 yaitu berjumlah $100 \%$ atau 39 siswa.

Pada siklus 1, berdasarkan perhitungan hasil observasi diperoleh nilai $64 \%$ yang artinya kegiatan pembelajaran yang disampaikan oleh guru masih kurang. Sedangkan, pada siklus 2, berdasarkan perhitungan hasil observasi diperoleh nilai 98,66 \% yang artinya kegiatan pembelajaran yang disampaikan oleh guru sangat baik.

Berdasarkan penjelasan di atas, penggunaan Metode Pembelajaran Mind Mapping dapat Meningkatkan Hasil Belajar Geografi Pada Siswa di Kelas XIIIPS 1 SMAN 5 Bekasi Pada Tahun Pelajaran 2018/2019.

Buzan (2007: 5) mengemukakan bahwa mind mapping akan memberi pandangan menyeluruh pada pokok masalah atau area yang luas. Selain itu juga, memungkinkan kita merencanakan rute atau membuat pilihan-pilihan dan mengetahui ke mana kita akan pergi dan di mana kita berada, begitu juga dapat mengumpulkan sejumlah besar data di satu tempat. Serta dapat mendorong pemecahan masalah dengan membiarkan kita melihat jalan-jalan terobosan kreatif baru. Mind mapping juga tentunya menyenangkan untuk dilihat, dibaca, dicerna dan diingat. Selain itu, Buzan (2007: 6) menyebutkan kelebihan mind mapping adalah: 1) Merencana. 2) Berkomunikasi 3) Menghemat waktu 4) Menyelesaikan masalah 5) Memusatkan perhatian 6)Menyusun dan menjelaskan pikiran-pikiran.7) Mengingat dengan lebih baik 8) Belajar lebih cepat dan efesien 9) Melihat "gambar keseluruhan".

Menurut evied an Lenz dalam bukunya Azhar Arsyad ( 2016: 16) menyatakan bahwa "Media pembelajaran, khususnya media visual (gambar) mempunyai 4 fungsi yaitu (a) fungsi atensi, (b) fungsi kognitif, (c) afektif serta (d) fungsi kompentsatoris". "Media visual (gambar) dalam proses belajar mengajar dapat mengembangkan kemampuan visual, mengembangkan imajinasi anak, membantu meningkatkan penguasaan anak terhadap hal-hal yang abstrak 
Research and Development Journal Of Education

Vol. 6 No. 1 Oktober 2019

p-ISSN 2406-9744

e-ISSN 2657-1056

atau peristiwa yang tidak mungkin dihadirkan dikelas". (Angkowo dan A Kosasih, 2017: 28). Secara singkat dapat dikatakan bahwa media gambar dapat meningkatkan hasil belajar siswa.

\section{SIMPULAN}

Berdasarkan deskripsi dan pembahasan penelitian maka simpulan dari penelitian yaitu sebagai berikut:

1. Pada pelaksanaan siklus 1, siswa yang mendapatkan nilai hasil belajar geografi di atas 75 berjumlah 34 siswa yang artinya yang tidak sesuai dengan kriteria keberhasilan tindakan yaitu berjumlah $87,17 \%$ dan siswa yang mendapatkan nilai geografi di atas 75 yaitu berjumlah 5 siswa yaitu berjumlah $12,83 \%$. Oleh karena itu, siklus 2 harus diadakan.

2. Pada pelaksanaan siklus 2, siswa yang mendapatkan nilai hasil belajar geografi di atas 75 berjumlah 39 siswa yang artinya sesuai dengan kriteria keberhasilan tindakan yaitu berjumlah $100 \%$ dan siswa yang mendapatkan nilai geografi di atas 75 yaitu berjumlah $100 \%$ atau 39 siswa.

3. Pada siklus 1 , berdasarkan perhitungan hasil observasi diperoleh nilai $64 \%$ yang artinya kegiatan pembelajaran yang disampaikan oleh guru masih kurang. Sedangkan, pada siklus 2, berdasarkan perhitungan hasil observasi diperoleh nilai 98,66 \% yang artinya kegiatan pembelajaran yang disampaikan oleh guru sangat baik.

\section{UCAPAN TERIMA KASIH}

Penulis mengucapkan terimakasih kepada Kepala Sekolah SMAN 5 Bekasi dan teman sejawat guru geografi di SMAN 5 Bekasi yang telah membantu penelitian ini, serta Siswa dan Siswi SMAN 5 Bekasi kelas XII-IPS 1 Pada Tahun Pelajaran 2018/2019. Penulis juga mengucapkan terima kasih kepada team RDJE.

\section{DAFTAR PUSTAKA}

Afandi, Widyo. 2011. Epistimologi Geografi. Yogyakarta Gajah Mada Press Arsyad, Azhar. 2016. Media Pembelajaran. Jakarta: Raja Grafindo Persada Angkowo R. dan A. Kosasih. 2017. Optimalisasi Media Pembelajaran. Jakarta PT. Grasindo.

Agus Supriyono. 2009. Cooperative Learning. Yogyakarta : Pustaka Pelajar. 
Research and Development Journal Of Education

Vol. 6 No. 1 Oktober 2019

p-ISSN 2406-9744

e-ISSN 2657-1056

Ahmad Susanto. 2013. Teori Belajar dan Pembelajaran di Sekolah Dasar. Jakarta: Kencana Prenadamedia Group

Buzan, Tony. 2007. Buku Pintar Mind Map. Jakarta : PT. Gramedia Pustaka Utama

Dimyati \& Mudjiono. 2013. Belajar Dan Pembelajaran. Jakarta: Rineka Cipta.

Donaldson, Thomas dan Lee E. Preston. 2012. The Stakeholder Theory of The Corporation : Concepts, Evidence, and Implications. The Academy of Management Review, Vol.20, No. 1, pp. 65-91.

Hamalik, Oemar. 2014. Proses Belajar Mengajar.Bumi Aksara. Jakarta.

Hartshorne, R. 2014. Perspective on the nature of geography. Chicago: RendMcNally \& Company.

Lounsbury, Floyd G. 2015. Linguistics and Psychology". Dalam Joshua A. Fishman (ed.). Reading in The Sociology of Language. The Huge-Paris: Mouton.

Nursid Sumaatmadja. 2018. Studi Geografi Suatu Pendekatan dan Analisa Keruangan. Alumni. Bandung.

Olivia, Femi. 2014. 5-7 Menit Asik Mind Mapping Kreatif. Jakarta : PT.Gramedia. Sudjana, N. 2014. Dasar-dasar Proses Belajar Mengajar. Bandung: Sinarbaru

Swadarma, Doni. 2013. Penerapan Mind Mapping dalam Kurikulum Pembelajaran. Gramedia. Jakarta.

Sumadi, 2013. Diklat Geografi Regional Indonesia. Pendidikan Geografi Jurusan IPS. FKIP. UNILA. Bandar Lampung.

Internet :

https://docplayer.info/29881218-Geografi-a-pengertian-dan-ruang-lingkup-ilmugeografi.html. 